\title{
A NEW JURISPRUDENTIAL FRAMEWORK FOR JURISDICTION: BEYOND THE HARVARD DRAFT
}

\author{
Dan Jerker B. Svantesson*
}

Eighty years ago, in 1935, a major step was taken in international law; the Harvard Research Draft Convention on Jurisdiction with Respect to Crime ("Harvard Draft") was published in the American Journal of International Law. ${ }^{1}$ The influence of the Harvard Draft has been nothing but phenomenal and must surely have exceeded the drafters' wildest ambitions. Indeed, it is fair to say that the structure put forward in the Harvard Draft has represented public international law's approach to jurisdiction ever since.

The most obvious reason the Harvard Draft has had such an enormous influence is of course found in the fact that it represents a sterling research effort performed by top scholars, resulting in a convenient summary of a complex topic, published in a prestigious outlet at the right moment in time. However, the Harvard Draft principles are ill-equipped for today's modern society characterised by constant, fluid and substantive crossborder interaction, particularly via the Internet. Here, I will thus argue that a paradigm shift is overdue and I will provide a sketch of what a new paradigm may look like.

\section{Territoriality-The "Crown Jewel" Of The Harvard Draft}

Essentially, the lasting legacy of the Harvard Draft is that it identifies a set of grounds for jurisdiction to varying degrees recognized under international law. Of those principles, the most important one is the territoriality principle_-described in the Harvard Draft as "everywhere regarded as of primary importance and of fundamental character."

However, the territoriality principle is particularly problematic in today's society and its application to the Internet has been challenging indeed. Early debates centred on the argument that it is difficult or even impossible to identify the location of online activities. While we need to continue that discussion e.g. in the context of cloud computing, as the debate has matured the greater concern is now that many online activities touch upon the territories of States without having any real substantial connection to those States. I think the discussions of these problems usefully can act as a catalyst for broad reform of how international law approaches jurisdiction. This reform is required in relation to legislative jurisdiction, adjudicative jurisdiction, enforcement jurisdiction as well as what I elsewhere have described as a fourth category, that of investigative jurisdiction. ${ }^{2}$

\footnotetext{
* Professor and Co-Director, Centre for Commercial Law, Faculty of Law, Bond University (Australia). Researcher, Swedish Law \& Informatics Research Institute, Stockholm University (Sweden). Professor Svantesson is the recipient of an Australian Research Council Future Fellowship (project number FT120100583). The views expressed herein are those of the author and are not necessarily those of the Australian Research Council.

Originally published online 03 November 2015.

${ }^{1}$ Draft Convention on Jurisdiction with Respect to Crime, 29 AJIL 439 (1935).

${ }^{2}$ Dan Jerker B. Svantesson, Will data privacy change the law?, OUPBLOG (May 31, 2015).
} 
However, before moving on to consider possibilities for a better approach to jurisdiction, it is worth noting that the Harvard Draft principles operate within a system—a dysfunctional system-with additional components such as (territorial) sovereignty, comity and the duty of noninterference.

It seems to me that there are few approaches to the issue of Internet jurisdiction that cannot both be supported, and at the same time objected to, by reference to public international law principles such as (territorial) sovereignty, comity, duty of nonintervention and the jurisdictional principles advanced in the Harvard Draft. Such is the state of international law as it relates to jurisdiction.

Consider, for example, the currently ongoing data privacy vs. law enforcement dispute between Microsoft on the one hand, and the U.S. Government on the other. ${ }^{3}$ In December 2013, the U.S. Government served a search warrant on Microsoft under the Electronic Communications Privacy Act of 1986. The warrant authorizes the search and seizure of information associated with a specified web-based e-mail account that is stored at Microsoft's premises. Microsoft has opposed the warrant since the relevant e-mails are located exclusively on servers in Dublin, Ireland, and argues that the U.S. enforcement activity is extraterritorial. ${ }^{4}$ In the sharpest contrast possible, the United States is saying that, as all activities required to retrieve the data can be taken from the United States, this is not a case of extraterritorial jurisdiction. ${ }^{5}$ The reality is that both claims are plausible, which signals that we are no longer, if we ever were, able to draw sharp lines between what is territorial and what is extraterritorial. This further undermines territoriality as the leading light in jurisdictional matters.

More broadly, the United States may argue that the territoriality principle, nationality principle and possibly protective principle all support its claim. It may perhaps even argue that Irish objections to the release of the relevant information violates Ireland's duty of nonintervention and interferes with U.S. sovereignty. At the same time, and with at least equal force, Ireland may argue that the U.S. warrant violates its territorial sovereignty and may point to the territoriality principle, the doctrine of comity and perhaps even the duty of noninterference.

This situation is nonsensical and the time has surely come to start over.

\section{The Method: From Proxy Principles To Core Principles}

To move forward, we must recognize that the territoriality principle, and the associated but partially clashing concept of territorial sovereignty, no longer serve as useful starting points for the analysis of jurisdictional claims. At least for practical reasons, we need to search for a better point of departure for such tasks.

I would, however, go as far as to suggest that the territoriality principle and all the other Harvard Draft principles are merely proxy principles for, and simplified expressions of, underlying core principles; they were after all constructed, through compromises, to reflect the legal practice at the time-they were a convenient summary of what courts did, what legislators thought and so on. I hasten to acknowledge that the Harvard Draft principles have been treated as jurisprudential core principles and therefore have assumed such a role on a practical level-they are the measuring stick against which jurisdictional claims are assessed. My claim is, however, that they never properly should have been viewed as such core principles, for they set inappropriately tight boundaries for our thinking and have left us unable to explore options that stray from the territoriality focus. At any rate, whatever the status of the Harvard Draft principles de lege lata, they should not be seen as jurisprudential core principles de lege ferenda. When, as in the current era, we are trying to apply the law to novel

${ }^{3}$ Dan Jerker B. Svantesson, After Microsoft v. U.S.-Law Enforcement in the Cloud (1 of 2), LinKEDIN PulSE (Dec. 31, 2014).

${ }^{4}$ Brief for Appellant, Microsoft Corporation v. United States (2d Cir.); for European Union-side, see Brief of Amicus Curiae Jan Philipp Albrecht, Member of the European Parliament, Microsoft Corporation v. United States (2d Cir.).

${ }^{5}$ Government's Brief in Support of the Magistrate Judge's Decision to Uphold a Warrant Ordering Microsoft to Disclose Records Within its Custody and Control, In re A Warrant to Search a Certain E-Mail Account Controlled and Maintained by Microsoft, 15 F. Supp. 3d 466 (S.D.N.Y. 2014). 
phenomena that require legal clarity, we need to cut away the undergrowth of proxy concepts and identify the core principles at stake. Only then will we be able to focus on the considerations and values that truly are to be balanced.

Thus, in order to go forward we must first take a few steps back and identify the jurisprudential core principles that, in my view, underlay the Harvard Draft's jurisdictional principles, and that represent a better jurisprudential paradigm for jurisdictional enquiries.

\section{The New Paradigm}

It would seem inappropriate to so strongly criticize the established thinking on jurisdiction without providing at least a sketch of what a new paradigm might look like. Conscious of the limits imposed by the format of a short essay such as this, I will do so here.

It seems to me that the essence of the jurisdictional principles expressed in the Harvard Draft may be distilled into two core principles; that is, in the absence of an obligation under international law to exercise jurisdiction, jurisdiction may only be exercised where (1) there is a substantial connection between the matter and the State seeking to exercise jurisdiction, and (2) the State seeking to exercise jurisdiction has a legitimate interest in the matter.

The Harvard Draft principles seek to rely on mechanical binary proxies such as territory and nationality as shortcuts avoiding the real, underlying, issues of substantial connection and legitimate interest-issues that always will be matters of degree rather than being binary. Under a new paradigm we would turn, or as I see it return, to these core principles.

Critics will no doubt hasten to question how my proposal relates to other, in some ways more complex, jurisdictional principles presented in the Harvard Draft: the protective principle and the universality principle. My answer to them is that the protective principle is, in fact, the clearest expression of a focus on substantial connection and legitimate interest. As to the universality principle, I think it appropriate to take the view that matters covered under its rubric are those which all States have a substantial connection to, and a legitimate interest in.

In addition to the two core principles noted above, I would like to advance a third: the balance between the State's legitimate interests and other interests. While this principle is not as clearly part of the Harvard Draft principles as the other two, it can nevertheless be seen in the application of, for example, the protective principle. Furthermore, including such balancing may allow us to use this set of core principles to replace other pieces of the puzzle; that is, the doctrine of comity and the duty of nonintervention as they apply in the jurisdictional context.

I have intentionally kept the wording of this element vague in that I make no commitment as to what type of interests may be considered. Under the current paradigm, it would seem that those interests would be limited to competing State interests. However, there may be reasons to broaden the scope so as to also take account, for example, of the interest of the party or parties being subjected to the jurisdictional claim, as well as the interests of the broader international community. This is a question that deserves to be discussed in detail. But that discussion cannot be adequately covered here.

The proposed paradigm shift from the Harvard Draft's proxy principles to the proposed core principles represents an important philosophical and theoretical change. However, if conducted carefully and diligently, on the practical level, the shift will be minimal in noncontroversial areas of jurisdiction. For example, a State would obviously have a substantial connection to, and a legitimate interest in, a traffic offense occurring within its territory, and the balancing principle between that State's legitimate interests and other interests ought not to cause any complications in such matters. The absolute majority of cases, both offline and online, will involve 
a similarly natural connection between territoriality on the one hand, and substantial connection and a legitimate interest on the other hand.

At the same time, the proposed paradigm shift would make us much better equipped to address what are now controversial areas. It will allow us to think more creatively rather than just in a mechanically binary fashion. It would, for example, free us from the thinking that a State always must have a possible jurisdictional claim over all aspects of data that happened to be located on a server located within its borders. For example, in the aforementioned Microsoft case, we would not simply ask the question of whether the U.S. law enforcement activity would take place on Irish territory or not. Rather we would ask questions such as whether the United States and Ireland, respectively, have a substantial connection to, and legitimate interest in, the matter, and what are the relevant interests to be balanced. In light of this, the usefulness of the proposed paradigm shift will be evident in the odd $5 \%$ of controversial cases and not in the standard $95 \%$ of cases.

Even if it is accepted that the paradigm shift's practical implications are restricted to exceptional cases, some may argue that the suggested paradigm shift would see us lose the simplicity that is provided by the mechanical binary proxy principles such as territory and nationality. And it is, of course, true that the core principles I advance are rather general and thereby vague. However, I argue that the mechanical simplicity provided by the proxy principles, at least the central territoriality principle, is an illusion. After all, if we cannot agree on when an activity takes place in a particular territory-which is the central point of dispute in the matter between Microsoft and the U.S. government - it is of little comfort that we may agree on the consequences that would follow if the activity takes place in a particular territory. Thus, my claim is this; the move to the core principles will admittedly introduce a broader scope for interpretation, at least until the application of the principles matures, but we are already faced with a comparable degree of vagueness.

There is another possible objection to what I am proposing. It could be argued that, even if we accept my core principles, their broad scope will incentivize and even necessitate the subsequent development of more specific proxy principles that, while drawing upon the core principles, will become widely used in practice. This is a valid concern, but I want to make two observations in response. First, I do not object to such a development, which may be both natural and desirable. However, it is of fundamental importance that where such proxy principles develop, they will at least be based on a clear and appropriate set of core principles, and so will be doing good as long as they stay true to those core principles. Second, the dominant Harvard Draft principles are, as noted, vague and broad in scope, and they have also resulted in the natural development of more precise principles helping in their actual application. So we will not be worse off and may be substantially better off.

\section{Unifying Public, And Private, International Law}

While the scope of this brief essay does not allow me to discuss it in any detail, I wish here to note my suspicion that the framework presented, with its three jurisprudential core principles, also may be viewed as a useful representation of the core of private international law (or conflict of laws as it also is called). This means that the principles I propose could be seen to not only hint at a convergence between public, and private, international law, but in fact constitute the common core that unites public international law and private international law.

As I have pointed to elsewhere, ${ }^{6}$ private international law often focuses on factors such as the following:

- the interests of the forum jurisdiction;

- the interests of other jurisdictions;

${ }^{6}$ DAN Jerker B. SVANTESSOn, Private InTERnational LAW AND the INTERnet (2nd ed., 2012). 
- the interests of the plaintiff;

- the interests of the defendant;

- the interests of any relevant third-parties;

- the plaintiff's contacts with the forum jurisdiction;

- the defendant's contacts with the forum jurisdiction;

- the plaintiff's contacts with other jurisdictions;

- the defendant's contacts with other jurisdictions;

- the relationship of the dispute with the forum jurisdiction; and

- the relationship of the dispute with other jurisdictions.

At least if the third of my proposed principles, interest balancing, is made wide enough to consider interests other than State interests, all of these factors may be traced back to the three core principles I advocate here.

Thus, while it may be true that, as a general rule, the jurisdictional principles in private international law are more closely focused on the parties, and the activities of the parties, while the jurisdictional rules under public international law are more focused on the States and State interest, both systems of jurisdictional rules may be traced back to the core principles I have identified.

\section{Concluding Remarks}

Some scholars have pointed to a correlation between, on the one hand, the spread of the use of techniques of mapping, which facilitate the abstraction of territory from the physical earth, and on the other hand the reliance on the concept of territoriality to act as a mediator between sovereignty/jurisdiction and the physical. As illustrated by the works of distinguished geographers, the online environment can also be "mapped" in many interesting ways. However, from a legal perspective the online environment maps in a different way to the physical world. Thus, the territoriality principle - the central pillar of the Harvard Draft principles—is not necessarily a natural leading light online.

I have here argued that we now-some eighty years after their publication-respectfully pull the curtain on the Harvard Draft principles. After all, given the complexity of jurisdictional considerations in today's society, the Harvard Draft principles are unrealistically mechanical. We have allowed the Harvard Draft to cement a 1930's conception of the world. They validate a dated and rigid focus on territoriality that makes impossible any progress with internet jurisdiction. It is no surprise that the principles found in the Harvard Draft are no longer part of any solution; they have become a part of the problem.

Furthermore, there is an increasing appreciation of the fact that, in a globalized world, State responsibilities do not end at the States' territorial borders. This is particularly clear in areas such as human rights law, environmental law and space law.

Abandoning the Harvard Draft principles represents a paradigm shift and will no doubt be associated with controversy and opposition. However, in the debates to be had about this, it is of fundamental importance to recall the limits the drafters themselves had in mind for the Harvard Draft principles; they were articulated in the penal context representing a simplified restatement of State practice and academic opinions at the time. Further, we should take into account the fact that the Harvard Draft principles are arguably merely proxies for underlying core principles. Thus, returning to the following three core principles may perhaps be surprisingly natural: 
In the absence of an obligation under international law to exercise jurisdiction, a State may only exercise jurisdiction where:

(1) there is a substantial connection between the matter and the State seeking to exercise jurisdiction;

(2) the State seeking to exercise jurisdiction has a legitimate interest in the matter; and

(3) the exercise of jurisdiction is reasonable given the balance between the State's legitimate interests and other interests.

In accepting these principles as the common core of jurisdiction both under public international law and private international law, we have also managed to bridge a gap too often perceived between these two areas of law. This advance in theory should lay the foundation for some very interesting future developments in relation to the crucially important concept of jurisdiction. 